anbiances Environnement sensible, architecture et espace urbain

\title{
Q\&A with Juhani Pallasmaa on Architecture, Aesthetics of Atmospheres and the Passage of Time
}

Questions-réponses avec Juhani Pallasmaa sur l'architecture, l'esthétique des ambiances et les effets du temps

\section{Michael Amundsen}

\section{OpenEdition}

\section{Journals}

Electronic version

URL: http://journals.openedition.org/ambiances/1257

DOI: $10.4000 / a m b i a n c e s .1257$

ISSN: 2266-839X

Publisher:

Direction Générale des Patrimoines - DAPA - MCC, UMR 1563 - Ambiances Architectures Urbanités (AAU)

\section{Electronic reference}

Michael Amundsen, «Q\&A with Juhani Pallasmaa on Architecture, Aesthetics of Atmospheres and the Passage of Time », Ambiances [Online], Reports, Online since 06 October 2018, connection on 21 December 2020. URL : http://journals.openedition.org/ambiances/1257 ; DOI : https://doi.org/ 10.4000/ambiances. 1257

This text was automatically generated on 21 December 2020.

\section{cc)}

Ambiances is licensed under a Creative Commons Attribution-NonCommercial-NoDerivatives 4.0 International License. 


\title{
Q\&A with Juhani Pallasmaa on Architecture, Aesthetics of Atmospheres and the Passage of Time
}

\author{
Questions-réponses avec Juhani Pallasmaa sur l'architecture, l'esthétique des \\ ambiances et les effets du temps
}

Michael Amundsen

1 In his long career Juhani Pallasmaa (1936) has established himself not only as a prominent architect in his home country of Finland and beyond but as a leading voice on the meanings of space. His contributions to architecture include most notably the Kamppi Centre (2003-2006), a massive and ambitious project in the centre of Helsinki, but also many smaller and more intimate works. As a philosopher, Pallasmaa's writings are wide ranging, touching on aesthetics, phenomenology and the relationship between the human condition, art and place. His book "The Eyes of the Skin - Architecture and the Senses" ${ }^{\prime}$ is a staple on reading lists in architecture schools and has had a crossdisciplinary impact globally.

2 In this review, Michael Amundsen presents his discussion with Juhani Pallasmaa on September 2018. It is the result of a preliminary telephone conversation that was formally constructed as a written Q\&A format answered by Pallasmaa in a second step. Their discussion touches upon Pallasmaa's vast experience and deep understanding of the meanings of space and the human experience of architecture. They look at themes of historical and societal impacts on the creation and experience of spaces, the meaning of time in architecture, and the politics and aesthetics of the built world.

\section{Architecture, atmospheres and architects}

Michael Amundsen (M.A.): To you, what does ambiance denote in a room or urban space? 
4 Juhani Pallasmaa (J.P.): The ambiance or atmosphere of a room or an urban space is the overall feeling and tuning of the experience. It is a non-material or peripheral experience (a "quasi-thing", as Tonino Griffero calls the phenomenon) that tunes our minds in a specific way. We feel atmospheres immediately and without being conscious of the process.

5 M.A.: When you think of architects of the 20th century who "got" atmospheres and incorporated them appropriately in their plans, who comes to mind?

6 J.P.: Usually, the architects of the "second tradition of modernism" (Colin St John Wilson's notion ${ }^{2}$ ) are atmospheric, due to their contextual, textural, tactile and material architectural languages, intimate scale and themes with variations of compositions. Of course, Mies van der Rohe's buildings, as well as constructivist and minimalist architectures also have their atmospheres, but they tend to be more cognitive than sensory.

7 M.A.: What about contemporary architects?

8 J.P.: The best architects today are atmospheric: Zumthor, Murcutt, Joy, Williams \& Tsien and the Patkau couple, for instance. M.A.: What are your thoughts on the Estonian-born Louis I. Kahn?

10 I have often written on Kahn, as he is one of the most significant architects of last century. He re-connected contemporary architectural thinking with the timeless traditions of architecture and the language of geometry. He also brought back a sense of the mystical to the architecture of our time, which tends to be intellectually and rationally biased.

\section{Ruins and the terror of time}

11 Michael Amundsen (M.A.): Could you speak about the meaning of ruins, especially in the urban context, and the ruins left by the socialist empire in Europe and beyond?

12 Juhani Pallasmaa (J.P.): Ruins have a strong mental and emotive presence and impact. They activate both our memories and imaginations. Ruins materialize history and time, and they also often turn arrogant or authoritarian architectural structures into humble and humane ones. Ruins seem to have a healing mental impact, as they invite us to reflect, dream and imagine.

13 M.A.: Can you discuss an effective way in which an architect might approach the problem of the "terror of time", as outlined by Karsten Harries"?

14 J.P.: We have a hidden fear of both the passing and disappearance of time and its endlessness. Karsten Harries, a philosopher, writes about the "terror of time". Architecture materializes history and mediates our relationship with both space and time; we dwell both in space and time, and architecture needs to "tame" both dimensions for us. I see this mediating task of architecture as more important than any subjective artistic expression. 


\section{Atmosphere and light}

Michael Amundsen (M.A.): When you are making a building, how do you go about "designing" an atmosphere for a given space?

Juhani Pallasmaa (J.P.): A talented architect internalizes his/her design and works with it in an intimate and multi-sensory manner, as if it were a part of him/herself. A gifted designer senses the hidden tactility and materiality, as well as the emotive and atmospheric impact. A mature architect does not compose a drawing, but the experience of the project in real life. The final target of the architect is not the physical building, but its impact as a lived experience. This is what John Dewey taught us with his seminal book "Art as Experience" in $1934^{4}$.

M.A.: Could you speak about the role that light plays in creating architectural space?

J.P.: Light is the most subtle of the means of architecture; it can express joy and happiness, as well as melancholy and sorrow. We do not "see" light directly, and architecture must somehow "materialize" light by means of reflecting surfaces, in order to bring light to our attention. James Turrell speaks of "tactile light" and "the thingness of light".

\section{Vision, manipulation and politics in architecture}

9 Michael Amundsen (M.A.): In "Eyes of the Skin", you discuss the "narcissistic and nihilistic eye", could you elaborate on these concepts here?

Juhani Pallasmaa (J.P.): The notion of the "narcissistic eye" refers to the selfcenteredness in vision, which is very evident in much of today's design and architecture. Yet, all significant art and design is about the world and the condition of being human in it, not self-expression. "We come not to see the work of art, but the world according to it" ${ }^{5}$, Maurice Merleau-Ponty writes significantly.

21 The "nihilistic eye" seeks to separate us from the world and our sense of reality. The nihilistic eye separates vision from its natural desire, to fuse with all the other sensations. It also annihilates existential meaning by turning architecture into a mere visual game. The ethical task of architecture is integration, not alienation.

M.A.: Could you discuss the political aspect of architecture? In the Soviet Union for instance, there were varied architectural styles, some quite appealing, like Stalin Gothic. What constitutes a totalitarian or democratic architecture?

3 J.P.: A "democratic architecture" mediates and expresses equality, and aims at liberating and dignifying individual experiences, instead of manipulating our experiences and feelings. Architecture is the opposite of entertainment; it strengthens our sense of the real, which also liberates independent dreaming.

4 All totalitarian regimes have used architecture to reinforce their position and message. Interestingly, all these political orientations have relied on classical language, except for the early utopian phase of Socialism in the Soviet Union and the Italian rationalism and futurism, which both produced exciting and liberating new architecture.

"There is always a bloody Corinthian column sticking out from the shoulders of totalitarian architecture", a famous art historian wrote. Architecture tends to seek and support power (even great architects in history have offered their services to 
oppressive rulers); today, it is the omnipotence of the quasi-rational economic and consumerist obsessions, to which architecture kneels.

M.A.: The world today is in a precarious place where norms, standards and freedoms are under threat. What might this mean for architecture?

J.P.: In my view, excessive norms, standards and regulations are a threat to architecture. Architecture is increasingly turning into a struggle with such regulations. Many of the norms are simply negative; for instance, regulations specify minimum levels of illumination, but we are biologically twilight animals, and maximum illumination levels would be needed as well to safeguard the optimal functioning of our eyesight.

It is another aspect entirely, that developers and construction companies tend to bypass benevolent and necessary regulations, such as structural standards, for purposes of profit.

M.A.: How do you feel surveillance impinges on the experience of urban and architectural space?

J.P.: Mentally and experientially, we need shadows and dark corners as much as exposure and surveillance, privacy more than exposure. The new technologies are making us increasingly exposed. Also, the tendency towards increasingly transparent buildings is an alarming example of the loss of shadow and privacy. "Modern houses would be better with only half of their window surface", Luis Barragan (1902-1988), the alchemist of modern architecture said in his Pritzker Prize speech.

\section{Architecture and the arts}

\section{Michael Amundsen (M.A.): Goethe called architecture "frozen music". Could you compare architecture with other art forms?}

Juhani Pallasmaa (J.P.): All art forms aim at expressing the human condition, our being in the world. Thus, artistic meaning is always existential. As the artistic essence of architecture, especially in our time, tends to be lost under a (quasi-)rationality, utility and manipulative aestheticization, the example of the arts is seminal for architecture. I always teach architecture through other art forms. Architecture is suspended between the world of utilitarian rationality and artistic existential expression, and this duality has to be understood, otherwise our craft will turn into a shallow service profession. Architecture needs its artistic autonomy, but that is quickly disappearing.

3 The notion of "frozen music" was first expressed by Schelling, not Goethe. Music is very close to architecture, because they both deal with unfocused, peripheral and atmospheric experiences. There is now an increasing interest in the neuroscience of architecture, but the neuroscience of music is much more developed, partly because music is a more formalized, disciplined and structured art form.

\section{M.A.: Architecture seems to be a very rationalistic art form. How can you incorporate the} irrational into this world?

J.P.: Architecture is many different things at the same time: rationality and emotion, utility and artistic mediation, calculation and belief, functionality and mental mediation, science and dreaming. This multiplicity makes a unified theory of architecture an impossibility. We can only have partial architectural theories; this was 
already pointed out by Alvar Aalto (1898-1976) in his inaugural lecture as member of the Academy of Finland in $1955^{6}$.

In my view, the existential reality in architecture is supported through one's interest in literature, poetry, cinema and the other arts. I always recommend looking at and listening to artworks, and reading books. This is the way to learn about the existential dimension of life. A lifeless architecture is always bad architecture.

\section{Architecture and the influence of history}

Michael Amundsen (M.A.): In the 20th century, Finland was in a very precarious state from invasion, and a nation caught between east and west. How do you feel this impacted the country's architecture?

Juhani Pallasmaa (J.P.): In my view, the threatened situations in Finnish political and social history have stimulated architectural intentions. In my view, architecture is an unconscious existential expression, and it is deeply tied with the prevailing collective mental situation, and, surprisingly, the high points of architecture do not seem to coincide with political and economic wellbeing, as one would expect; the best architecture has arisen from threats and crises of some sort. I believe that societies have no capacity to learn, only individuals can.

39 M.A.: In Harold Bloom's "The Anxiety of Influence" he noted the impact that the poetry of the past had on later poets and the problem of "escaping", or, in some way, dealing with their influence without being derivative. Is this a problem that plagues architects as well?

40 J.P.: I believe strongly in the seminal significance and influence of tradition. A sense of tradition is the rudder that guides individual creativity. Through aging and experience, I have become conscious of the significance of tradition, not as given stylistic frames, but in the sense of a cultural continuum that also gives meaning to new things. We all work in a cultural continuum, and our work is inspired by our predecessors, and the most radical works of our time give new meanings to the works in history. Creative work is always collaboration. We all need "a historical sense", as T.S. Eliot (1888-1965) writes in his influential essay "Tradition and the Individual Talent" in $1919^{8}$.

41 M.A.: Today's architecture can seem very flimsy and ephemeral compared to the buildings of the ancient world or the middle ages. What do you feel we can learn from the architecture of the classical world, like the Pantheon in Rome?

42 J.P.: The ancient and historical masterworks teach us the meaning of the cultural continuum. They also make us understand that the mental, spiritual and artistic aspirations in architecture have not fundamentally changed; architecture still articulates and expresses the human condition, aspires to find meaning in existence, to mediate between ourselves and the world, and to elevate or dignify our lives. Art is a miraculous phenomenon in being independent of time. "An artist is worth a thousand centuries", Paul Valéry wrote. It is truly miraculous that thirty-thousand-year-old cave paintings are as vivid as any art of our own day. In the arts, you can travel centuries back and forth, and the time element as a linearity has no relevance for the power of the emotive encounter. In every individual experience, the work is re-born in its sensory and mental essence, so mentally, artworks exist in a timeless present. 


\section{World architecture and today's trends} mobile phones and other digital communications media revealed that they have lost their capacity to identify human facial gestures and emotions that our faces mediate. Quite disturbing, is it not?

\section{NOTES}

1. See: Pallasmaa, Juhani. 1996. The eyes of the skin: architecture and the senses. London: Academy Editions.

2. See: St John Wilson, Sir Colin. 1979. Architecture-Public Good and Private Necessity. RIBA Journal. vol. March. p. 107-115.

3. See: Harries, Karsten. 1982. Building and the Terror of Time. Perspecta. vol. 19, p. 58-69 
4. See: Dewey, John. 1989 [1934]. Art as Experience. In: Boydston, J. (ed.) John Dewey: The Later Works, 1925-1953. Carbondale: Southern Illinois University Press. vol. 10, p. 1-4

5. See: Merleau-Ponty, Maurice. 1962. The Phenomenology of Perception. London: Routledge.

6. See: Aalto, Alvar. 1991. Art and technology. In: Schildt, G.(ed.) Alvar Aalto in His Own Words. Helsinki: Otava.

7. See: Bloom, Harold. 1973. The Anxiety of Influence. A Theory of Poetry. New York: Oxford University Press.

8. See: Eliot, Thomas Stearns. 1997. The Sacred Wood and Major Early Essays. New York: Dover Publication. p.27

9. See: Valéry, Paul. 1956. Dialogues. New York: Pantheon Books.

\section{INDEX}

Mots-clés: ambiances, architecture, ruines, politique, arts

Keywords: atmospheres, architecture, ruins, politics, art

\section{AUTHOR}

\section{MICHAEL AMUNDSEN}

Michael Amundsen holds a doctorate from the School of Humanities at Tallinn University in Estonia. His work has been diverse and has looked at literature, especially the Beat Generation, and urban situations and spaces from busking to the architectural legacy of the former Soviet Union. He is the editor of Baltic Publishing, an academic publisher in Estonia, and is a journalist who has written for the Guardian and Financial Times among others. He has taught humanities and English literature at San Francisco State University, Tallinn University and the Estonian Academy of Art.

Contact: info@balticpublishing.com 